\title{
食物アレルギーと栄養指導
}

\author{
海老澤元宏 ${ }^{1 ｝ \text {, 林 典子 }{ }^{1 ）} \text {, 長谷川実穂 }{ }^{1)}$ \\ 杉崎千鶴子 1 ), 今井 孝成 ${ }^{2)}$ \\ 1) 国立病院機構相模原病院臨床研究センターアレルギー性疾患研究部 \\ 2) 国立病院機構相模原病院小児科
}

\section{Food Allergy and Nutritional Care}

\author{
Motohiro Ebisawa ${ }^{1}$, Noriko Hayashi ${ }^{1}$, Miho Hasegawa ${ }^{1}$, Chizuko Sugizaki ${ }^{1}$ and Takanori Imai ${ }^{2}$ \\ ${ }^{1}$ Department of Allergy, Clinical Research Center for Allergology and Rheumatology, \\ National Hospital Organization, Sagamihara National Hospital \\ ${ }^{2}$ Department of Pediatrics, National Hospital Organization, Sagamihara National Hospital
}

\begin{abstract}
The number of food allergy patients has been increasing, particularly in the developed nations. Japanese figures indicate that the prevalence of food allergy in infants is approximately $5-10 \%$ and approximately $2 \%$ in school children ${ }^{1)}$. It is necessary to establish the best way to manage food allergic children that participate in the school lunch program in nursery schools, kindergartens and higher schools. Registered dietitians therefore have to get the latest knowledge and information on food allergy to provide nutrition counseling for food allergy patients. This review article should be useful for registered dietitians who see food allergy patients so that their quality of life and that of their parents and guardians can be improved.
\end{abstract}

Jpn. J. Nutr. Diet., 68 (3) 157 165 (2010)

Key words: food allergy, food labeling, nutrition counseling, elimination diet, QOL(quality of life)

\section{食物アレルギーの診療}

1. 食物アレルギーの正しい理解

「食物を摂取した後に免疫を介してじんましんや呼吸困 難など体にとって不利益な症状が起こること」を食物ア レルギーという。この10年〜20年の間に食物アレルギー 患者がわが国も含めた先進国を中心にして増加しており 社会問題となってきている。正確な調査で増加が確認さ れているわけではないが, 我々が行った厚生労働省科学 研究の調査などから現在わが国では 1 才の 10 人に 1 人, 3 才で 20 人に 1 人, 学童で 50 人から 100 人に 1 人が何らか の食物に対してアレルギーを起こすと推定されている ${ }^{2)}$ 。 一般の人がよく誤解することだが，食物に含まれている 化学物質（例えばトマトやホウレンソウや鮮度の落ちた 青魚などに含まれるヒスタミンなど）による作用や乳糖 を体質的に分解できずに下痢を起こす乳糖不耐症などは 食物アレルギーには含めない。食物アレルギーのメカニ ズムの大部分は $\mathrm{IgE}$ (免疫グロブリン $\mathrm{E}$ ) という生体内の 微量なたんぱく質が介在して起こるものである。 IgE 抗 体は皮膚・腸粘膜・気管支粘膜・鼻粘膜・結膜などにい
るマスト細胞に結合した状態で食物アレルゲン（アレル ゲンとはアレルギー反応を起こすもとの IgE 抗体と結合 するたんぱく質）と出会うことによりマスト細胞から化 学伝達物質〔ヒスタミン（かゆみを起こしたり，くしゃ み・鼻水を出させる物質)・ロイコトリエン（気管支を収 縮させたり，鼻づまりを起こす物質）など〕が放出され アレルギー反応が引き起こされる。その結果，じんまし $ん \cdot$ 紅斑・下痢・嘔吐・咳・喉頭浮腫・喘鳴・呼吸困難 などの症状が誘発されるのである。つまり $\operatorname{IgE}$ 抗体依存 性の食物アレルギーでは摂取した食物がアレルギー反応 を起こす能力を持った状態で消化管から吸収された後, 血液を介して皮膚・気管支粘膜・鼻粘膜・結膜などに到 達してアレルギー反応が起きるのである。 IgE 抗体依存 性の反応の場合には食物を摂取した直後から 2 時間以内 ぐらいにアレルギー反応を認めることがほとんどである。 したがって食物アレルギーを起こす物質は基本的には食 物中のたんぱく質（アミノ酸が数個つながったペプチド も含む）である ${ }^{2)}$

どのような物質に対して体が IgE 抗体を作るかはある

キーワード：食物アレルギー，食品表示，栄養指導，除去食，QOL

(連絡先 : 海老澤元宏 ₹228-8522 神奈川県相模原市桜台18-1 国立病院機構相模原病院臨床研究センターアレルギー性疾患研究部 電話 042-742-8311 FAX 042-742-5314 E-mail m-ebisawa@sagamihara-hosp.gr.jp) 
程度遺伝的素因に基づいていると考えられている。最近 は両親がアレルギー素因を高率に有しているので，生ま れてくる子どもたちに食物アレルギーが増加していると 考えられているが理由は不明である。わが国で多く認め られる食物アレルギーの原因食品は卵・牛乳・ 小麦・甲 殼類・果物類・ソバ・魚類・ピーナッツ等であるが，食 物アレルギーは小児と成人で原因食品が異なり, 色々な 臨床病型が存在する ${ }^{3)}$ 。

\section{2. 食物アレルギーの症状と臨床病型}

食物アレルギーの症状として表 1 に示すような症状が 皮膚・粘膜, 呼吸器, 消化器などに出現する ${ }^{3)}$ 。アナフィ ラキシーショックと言い, 即時型症状に引き続き血圧低 下により脱力状態に陥り, 緊急に対応しないと生命に影 響を及ぼす場合もあるので注意が必要である。摂取アレ

\section{表 1 食物アレルギーにより引き起こされる症状}

\section{- 皮膚粘膜症状：}

皮膚症状 : 瘙痒感, じんましん, 血管運動性浮腫, 発 赤, 湿疹

眼症状：結膜充血・浮腫，瘙痒感，流涙，眼瞼浮腫 口腔咽喉頭症状 : 口管・口唇・舌の違和感・腫張，喉 頭絞扼感，喉頭浮腫，㖽声，喉の痒み・イガイガ感

\section{- 消化器症状}

腹痛，悪心，嘔吐，下痢，血便

- 呼吸器症状 :

上気道症状：くしゃみ, 鼻汁, 鼻閉

下気道症状：呼吸困難，咳嗽，喘鳴

- 全身性症状：

アナフィラキシー：多臟器の症状

アナフィラキシーショック：頻脈, 虚脱状態（ぐっ たり）・意識障害・血圧低下
ルゲンの量や年齢によっても出現する症状が異なり，授 乳期には母乳中の微量な $\left(\mu \mathrm{g}\right.$ レベル $\left.=10^{-6} \mathrm{~g}\right)$ アレルゲ ン (ペプチド) が関連して慢性的な痒みを伴う湿疹（顔 面から始まることが多い）を呈することが多く，離乳期 以降本人が直接食物（ $\mathrm{g}$ レベル）を摂取すると，幼児・ 学童・成人でじんましん・紅斑などの皮膚症状や呼吸困 難などの急激な反応（即時型症状）が出現することが多 くなる ${ }^{4,5)}$ 。乳児期（特に授乳期）のアトピー性皮膚炎に 食物が原因として関与することは多いのだが，幼児・学 童と成長に伴い食物アレルギーがアトピー性皮膚炎の原 因として関与する例は少なくなっていく。乳児期にアト ピー性皮膚炎に伴って発症し年齢とともに治っていく夕 イプ（食物アレルギーの関与する乳児アトピー性皮膚炎） は，原因として卵・牛乳・小麦・大豆が多く認められ， 湿疹症状から即時型へタイプが变わりながら小学校入学 までに約 $8 \sim 9$ 割が寛解していく $3,6,7) 。$ 幼児から成人に 新たに発症する夕イプでは主に即時型症状を呈し原因と してソバ・ピーナッツ・魚類・甲殼類・果物などが多く， 治っていくことが乳児期発症例に比べて少ないと考えら れている。即時型のタイプの特殊型で最近増えていてい る食物アレルギーに「口腔アレルギー症候群」があり， 幼览・学童・成人に果物（キウイ，バナナ，メロン，モ モ，パイナップル，リンゴなど）や野菜などで口の粘膜 や口周囲の皮膚にじんましん反応を起こすことがある。 花粉と果物などのたんぱく質の類似性が原因の例では, シラカバ，ハンノキなどの樹木の花粉症との関連性が指 摘されている。南方系のフルーツのバナナやマンゴなど はラテックス（ゴム）との関連性もある。果物アレルゲ

表 2 臨 床 型 分 類

\begin{tabular}{|c|c|c|c|c|c|c|}
\hline \multicolumn{2}{|c|}{ 臨 床 型 } & 発症年齢 & 頻度の高い食物 & $\begin{array}{l}\text { 耐性の獲得 } \\
\text { (寛解) }\end{array}$ & $\begin{array}{l}\text { アナフィ } \\
\text { ラキシー } \\
\text { ショック } \\
\text { の可能性 }\end{array}$ & $\begin{array}{c}\text { 食物アレルギー } \\
\text { の機序 }\end{array}$ \\
\hline \multicolumn{2}{|r|}{ 新生児消化器症状 } & 新生児期 & 牛乳（育児用粉乳） & $(+)$ & $( \pm)$ & $\begin{array}{c}\text { 主に } \\
\mathrm{IgE} \text { 非依存型 }\end{array}$ \\
\hline \multicolumn{2}{|c|}{$\begin{array}{l}\text { 食物アレルギーの関与す } \\
\text { る乳児アトピー性皮膚炎* }\end{array}$} & 乳 児 期 & 鶏卵，牛乳，小麦，大豆など & $\begin{array}{c}\text { 多くは } \\
(+)\end{array}$ & $(+)$ & $\begin{array}{c}\text { 主に } \\
\operatorname{IgE} \text { 依存型 }\end{array}$ \\
\hline \multicolumn{2}{|c|}{$\begin{array}{c}\text { 即時型症状 } \\
\text { （じんましん，アナフィラ } \\
\text { キシーなど） }\end{array}$} & $\begin{array}{l}\text { 乳児期〜 } \\
\text { 成 人 期 }\end{array}$ & $\begin{array}{l}\text { 乳児〜幼児 : 鶏卵, 牛乳, 小 } \\
\text { 麦, そば, 魚類など } \\
\text { 学童〜成人 : 甲殼類, 魚類, } \\
\text { 小麦, 果 物 類, そば, } \\
\text { ピーナッツなど }\end{array}$ & $\begin{array}{l}\text { 鵎卵, 牛乳, } \\
\text { 小麦, 大豆など } \\
(+) \\
\text { その他の多く } \\
( \pm)\end{array}$ & $(++)$ & IgE 依存型 \\
\hline \multirow{2}{*}{$\begin{array}{l}\text { 特 } \\
\text { 殊 } \\
\text { 型 }\end{array}$} & $\begin{array}{c}\text { 食物依存性運動誘発 } \\
\text { アナフィラキシシー } \\
\text { (FEIAn/FDEIA) }\end{array}$ & $\begin{array}{l}\text { 学童期〜 } \\
\text { 成人 期 }\end{array}$ & 小麦, エビ, イカなど & $( \pm)$ & $(+++)$ & $\operatorname{IgE}$ 依存型 \\
\hline & $\begin{array}{c}\text { 口腔アレルギー症候群 } \\
(\mathrm{OAS})\end{array}$ & $\begin{array}{l}\text { 幼児期 } \\
\text { 成 人 期 }\end{array}$ & 果物・野菜など & $( \pm)$ & $(+)$ & $\mathrm{IgE}$ 依存型 \\
\hline
\end{tabular}

* 慢性の下痢などの消化器症状，低たんぱく血症を合併する例もある。 全ての乳児アトピー性皮膚炎に食物が関与しているわけではない。 
ンの場合には加熱処理することによりアレルゲン性が減 弱あるいは消失してしまうことも多く認められる。例え ば, リンゴアレルギーで生では症状が出現しても焼きリ ンゴは摂取可能である場合も多い。もう一つの即時型食 物アレルギーの特殊型のまれな食物アレルギーで, 特定 の食物と運動の組み合わせでじんましんから始まり呼吸 困難, そしてショック症状にいたる場合を「食物依存性 運動誘発アナフィラキシー」と言う。我が国では原因と しては小麦・エビ・イカなどが多く報告されている。原 因食品を含む昼食を摂取した後 2 時間以内にサッカーな どの激しい運動をした場合にじんましんから始まり，呼 吸困難・ショックにいたるような例が典型的である。食 物単独, 運動単独では何も起こらないので, 病気の概念 を知らないと診断がつかないこともある。以上述べてき たことをわかりやすくコンパクトにまとめた表が厚生労 働科学研究班による「食物アレルギーの診療の手引き 2008」に示されており表 2 に示すので参考にして欲し $\omega^{8,9)}$

\section{3. 食物アレルギーの診断}

食物アレルギーは食生活に直結した身近な問題なので, 患者さんや保護者の方が食生活で経験的に「ある食物に 対してアレルギーがある」と自己診断されているケース も多い。自己診断が必ず間違っているとは言わないが, 食物アレルギーの診断は専門の医師にも難しい場合もあ る。食物アレルギーの症状と臨床病型について説明した が, 即時型症状の場合には誰の目にも明らかな症状が出 現するので原因食物の診断はそれほど難しくない。「食物 アレルギーの関与する乳児アトピー性皮膚炎」の場合に は湿疹がコントロールされていない状況では判断が困難 になる。このタイプの発症時の大きな特徴として生後 数ヶ月以内に顔面から始まる掻㾕の強い, ステロイド外 用療法に抵抗性の湿疹が見られることである。保護者が 子供のアトピー性皮膚炎の湿疹が悪い状態にあると食物 にすべての原因を求めてしまうこともあるが, 湿疹のコ ントロールが悪いと非特異的なこと（体温の変化, 入浴 など）で発赤などの症状が誘発されたように見えてしま うことも一因である。食物アレルゲンに対する $\operatorname{IgE}$ 抗体 の検査や皮膚テストによる $\operatorname{IgE}$ 抗体の証明が診断の補助 的意味しか持たないことも食物アレルギーの診断を難し くしている。最終的には, 食物除去・負荷試験によって 食物アレルギーの診断を行う。食物負荷試験は, 専門医 において施行されるべきである。各都道府県に最低 1 施 設程度食物負荷試験を正しく行える施設を配置できたら と思い, 厚生労働科学研究班において食物負荷試験ネッ トワークを2001年から立ち上げて活動を続けてきており, 現在参加施設も30施設以上になり累計で2, 000以上の共通 のプロトコールで行われたデータが集積し成果が上がっ
ている。血液検査や皮膚テストによる $\operatorname{IgE}$ 抗体の検査は 以前から保険診療点数が認められていた。しかし, 食物 負荷試験の診療報酬は，ようやく2006年に入院で，2008 年に外来で食物アレルギーの診療経験の豊富な医師が緊 急対応できる環境であれば認められるようになり，最近 はより多くの施設で行われるようになってきた。全国513 か所の日本小児科学会研修施設を対象に2009年度の食物 負荷試験の実施の有無および症例数について郵送で調査 票を送付したところ，外来における負荷試験実施施設は 134 か所，入院負荷試験実施施設は155か所において行わ れていた。調查結果を食物アレルギー研究会ホームペー ジ (http://foodallergy.jp/) で公開しているので参考にし て欲しい。

食物負荷試験では即時型症状が出現することが多く危 険も伴うので安易に家庭などで行うように指導すべきで はない。診断に関連して問題のあるケースとして，保護 者が食物をとらせると子供が痒がるからと食物制限を自 分でどんどんエスカレートしてしまったり，「アトピー性 皮膚炎には食物アレルギーは関係ない」と医師から相手 にされず正しい診断が受けられていなかったりするケー スである。逆に血液検査や皮膚テストが陽性という理由 だけでずっと必要のない食物除去を指導されている場合 もある。同じ食物負荷試験でも年齢に応じて正しい方法 で行わないと診断を誤る場合もある。3才ぐらいまでは 通常オープン負荷試験（食べるものがわかって行う検査） で問題ないが，4才，5才ぐらいから（特に食物除去を ずっと厳格に続けていたケースでは）食物負荷試験で負 荷食品が明らかな状態で行うと恐怖感や違和感などから 腹痛・かゆみなど本人にしか分からない症状（主観的症 状）を訴え，判断できないことがある。心因により主観 的な症状を訴える場合はブラインド負荷試験にしてプラ セボ (偽物) と比較をして初めて診断可能になる。この 様に食物アレルギーの診断を正しく行うことは意外に難 しいのだが，「正しい診断による必要最小限の食物除去」 が唯一の食物アレルギーの治療法なので診断は食物アレ ルギーの大変重要なパートをしめるのである。即時型症 状の診断をする場合にはアナフィラキシーを繰り返さな いように確定診断がなされることを第一優先にする。ア ナフィラキシーを確実に起こした原因アレルゲンがわ かっているような場合には逆に食物負荷試験は危険であ り適応にならない。食物負荷試験の適応と禁忌をアレル ギー専門医が判断することも大切な役目である。

\section{4. 食物アレルギーの治療と予防}

「正しい診断による必要最小限の食物除去」が食物アレ ルギーの唯一の治療なので, 食物アレルギーに対しての 薬物療法は補助的な位置づけである。小览期では特に食 物アレルギーと診断した後の定期的なフォローが大切で 
ある。小児期の食物アレルギーの中で最も多い「食物ア レルギーの関与する乳児アトピー性皮膚炎」ではそのほ とんどが乳児期に発症し， 3 才までに約 5 割，小学校入 学までに約 8 ～ 9 割が寛解する ${ }^{2,6,7)}$ 。したがって「食べ られるようになったのでは」ということを前提に定期的 に特異的 $\operatorname{IgE}$ 抗体検査や食物負荷試験を行う必要がある。 乳児期に発症する食物アレルギーは卵・牛乳・ 小麦・大 豆の順に頻度が多いが，一般的に改善が見られる順番は 頻度の多さに反比例し大豆・小麦・牛乳・卵の順である。 しかし食物アレルギーは原因, 治り方, 検査データが同 じ患者は存在しないので, 個別に的確に診断し対応して いくことが重要である。

幼児・学童から成人にかけて発症する即時型のタイプ では原因食品はソバ・ピーナッツ・魚類・甲殼類・果物 類などが多く，経過を見ていくと乳児期に発症する夕イ プに比べ大分治りにくいのでより慎重に経過を追ってい く必要がある。

薬物療法を食物アレルギーの患者に行う場合は原因食 品を誤って摂ってしまい症状が出現した場合やアトピー 性皮膚炎などを合併している場合などに限定される。ア レルギー反応ではヒスタミンという物質が体内で放出さ れ痒み・じんましん・鼻症状を誘発するので症状を抑え るために抗ヒスタミン薬はよく用いられる。重篤な場合 には短期間の経口ステロイドも有効であるが即効性はな いので注意が必要である。

食物アレルギーの発症予防には妊娠中も授乳中も特に 母親の食物の制限は必要はないが, つわりの時にありが
ちな「ある特定のものしか食べない」など偏食をしない ことは大切である。重症化を予防するという観点から乳 児で痒みを伴うアトピー性皮膚炎を疑うようなケースで スキンケア・ステロイド外用療法を行っても再燃し治療 に抵抗性な場合には食物アレルギーの可能性を考えて早 期に診断し対応することが大切である。そのことにより 食物アレルギーの耐性の獲得も早期に達成することが可 能である。

食物アレルギーの治療は色々な可能性を模索し世界中 で研究が進んでいる。「抗 IgE 抗体療法」といって月 1 回 の注射で $\operatorname{IgE}$ 抗体がマスト細胞と結合しなくなるように する療法もアメリカでは臨床治験が行われている。また 年長になっても寛解しないアナフィラキシータイプの食 物アレルギーに対して経口減感作療法といって軽微な症 状は無視して体を過敏な食物に対して慣れさせるような 研究も欧米で有効性が報告され ${ }^{10)}$ ，日本でも我々の施設 を含め数施設でパイロット的な研究が行われている。食 物負荷試験を行った上で如何に上手く原因食品を食べさ せていくかと言うことは重要になっていくと考えている。

5. 食物アレルギーによるアナフィラキシーとその対策 食物アレルギーによる即時型症状の最重症の反応をア ナフィラキシーといい, 原因食物を摂取して遅くとも 1 時間以内に症状が出現する。症状が出現した際には抗七 スタミン薬やステロイド内服が必要だが, 循環器症状 （血圧の低下・頻脈など）を伴うアナフィラキシーショッ クでは生命に関わることもあるので緊急の対応が必要に なる。2005年 4 月からわが国でも食物や薬物によるアナ
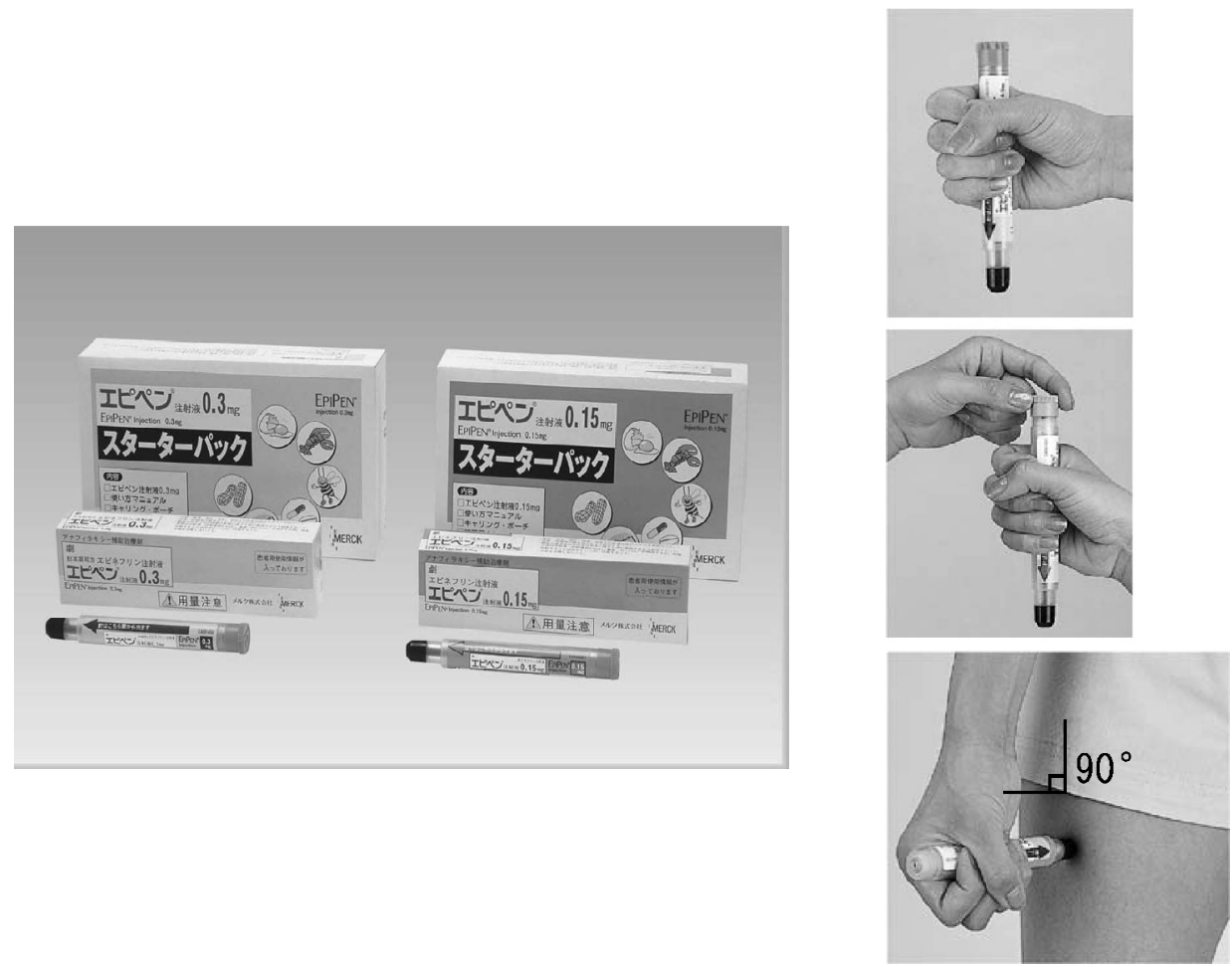

写真 1 エピペン ${ }^{\circledR}$ とその使用法 
フィラキシーショックに対して自己注射用アドレナリン 製剤（エピペン ${ }^{\circledR}$ 写真 1 ）が成人と小児に対してようや く承認された。今までは患者自身が身を守る方法は医療 機関に駆け込むしかなかったのだが，患者や保護者が ショック時に緊急避難的に用いる防衛手段を手に入れた のである。ペン型のバネ仕掛けの注射器で $0.3 \mathrm{mg}$ と $0.15 \mathrm{mg}$ の製剤があり, 素人でも簡単に太腿の外側にズ ボンの上からでも注射できる。食物によるアナフィラキ シーショックの場合には発症後30分以内に注射できるか どうかがポイントで，特に医療機関にアクセスの悪いと ころでアナフィラキシーを起こした場合に威力を発揮す る。使用するタイミングとしては喉頭浮腫や下気道の閉 塞による呼吸困難等が出現した時が適応である ${ }^{8)}$ 。エピペ ン $の$ 認可の他にも食物アレルギーによる重篤な反応を 起こす方への対応策が世界に先駆けて日本で行われてい る。2002年の 4 月から食品衛生法による「アレルギー物 質を含む食品の表示」が始まり, 加工品のラベルには 卵・牛乳・小麦・ソバ・ピーナッッの 5 品目は微量でも 含まれている場合に表示することが義務化されたのであ る。それ以前には原材料の $5 \%$ 未満の微量に含まれてい る原材料の表示義務はなく食物アレルギーの患者にとっ てはスーパーやコンビニエンスストアでは買い物ができ ない状況であった。2008年 6 月（ただし猶予期間 2 年） からエビ・カニは義務表示化された（表 3 )。その他まだ 解決しなくてはいけない問題が山積しており, 厚生労働 科学研究の“食物アレルギーの研究班”において「食物

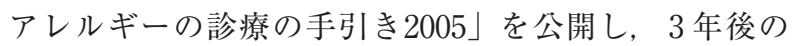
2008年に改訂が行われた。食物アレルギーは近年急増し てきたので医師により食物アレルギーの対応や考え方が 異なっていることも大きな問題になっている。食物アレ ルギーの診療のレベルの向上と患者の生活の質の改善を

表 3 食品衛生法 加工食品に含まれるアレルギー表示

\begin{tabular}{|c|c|}
\hline \multicolumn{2}{|r|}{ 特定原材料等の名称 } \\
\hline 義 務 & 卵, 乳, 小麦, えび, かに, そば, 落花生 \\
\hline 推 奨 & $\begin{array}{l}\text { あわび, いか, いくら, オレンジ, キウイフルー } \\
\text { ツ, 牛肉, くるみ, さけ, さば, ゼラチン, 大 } \\
\text { 豆, 鷄肉, バナナ, 豚肉, まつたけ, もも, やま } \\
\text { いも, りんご }\end{array}$ \\
\hline
\end{tabular}

アレルギー表示 $Q \& A$

http://www.mhlw.go.jp/topics/0103/tp0329-2b.html

平成14年 4 月より，発症頻度が多いか重篤な症状を誘発 しやすい食物（特定原材料等）に対して，微量（数 $\mu \mathrm{g} / \mathrm{g}$ 以上）でも含有している場合は，原材料表示されるように なった。但し表示の対象は容器包装された加工食品のみで, 店頭販売品や外食は対象外である。除去食を実践する上で 重要な情報であり，患者および保護者に情報提供するべき である。平成 20 年 6 月よりえび・かにが義務表示に追加さ れた。
目的に専門家が集まり作成している。医師のみならず一 般の方にも分かりやすく解説されており, 食物アレル ギー研究会 (http://foodallergy.jp/)，国立病院機構相模 原病院臨床研究センター (http://www.hosp.go.jp/ sagami/rinken/crc/index.html）などの HP から PDF ファイルで誰でも無料で入手可能である $(\text { 写真 } 2)^{8,9)}$ 。

\section{食物アレルギーの栄養指導}

\section{1. 食物アレルギーの栄養指導の必要性}

厚生労働科学研究班によって「食物アレルギーの栄養 指導の手引き2008」（主任研究者 今井孝成）が作成され た $(\text { 写真 } 2)^{11)}$ 。食物アレルギーの治療では, 正しい診断 に基づいた必要最小限の原因食物の除去が原則となる。 原因食物の除去を余儀なくされる患者や家族にとって, 特定の食物を除去することにより栄養素の摂取不足が生 じること，“食べてはいけない”食物を誤食して症状が出 るのではないかという不安や, 周囲の不理解などによっ て，“食べること”が生活の中で大きなストレスとなる可 能性がある。そのため食物アレルギー患者や家族には治 療の一環として，食物除去の指示と同時に，除去食生活 において適切に栄養素を摂取することや，除去による生 活の質（QOL）の低下を防ぐための栄養指導という食生 活の支援が必要となる。

さらに食物アレルギー患者に対する栄養指導では, 単 に食物の除去や栄養素摂取の方法を説明するだけでなく， 食物アレルギーの正しい知識に基づて患者や家族の疑 問や悩みを軽減し, 食物アレルギー患者が “食べること” を楽しむための総合的な支援をすることが求められる。 しかし，現状では全ての食物アレルギー患者が充分に栄 養指導を受けられる状況にはなく，この手引きをきっか けとして多くの管理栄養士が食物アレルギーについての 正しい知識を持ち，専門的な観点から積極的に患者の支 援に関わっていくことが期待される。

\section{2. 栄養指導の目的}

食物アレルギー患者は, 治療の一環としての除去食生 活中であっても，適切な栄養素を摂取し，その QOL を 維持する必要がある。しかし，厚生労働科学研究班の調 査結果から, 栄養面では, 特に牛乳アレルギー患者のカ ルシウム摂取量は国民健康・栄養調査の結果と比較して 顕著に不足していた。また，患者の除去食物が増えるほ どその QOL が低下することや， 食物アレルギー患者の保 護者が常に“食物アレルギー症状が起こるのではないか” という不安を抱えながら生活をしていることも明らかと なった。このため, 食物アレルギー患者に対しては, 食 物除去をしながらでも充分な栄養素を摂取するという 「健康的な食生活」, 食物アレルギーの正しい知識を取得 し，誤食のない食生活を送る「安心できる食生活」，食物 


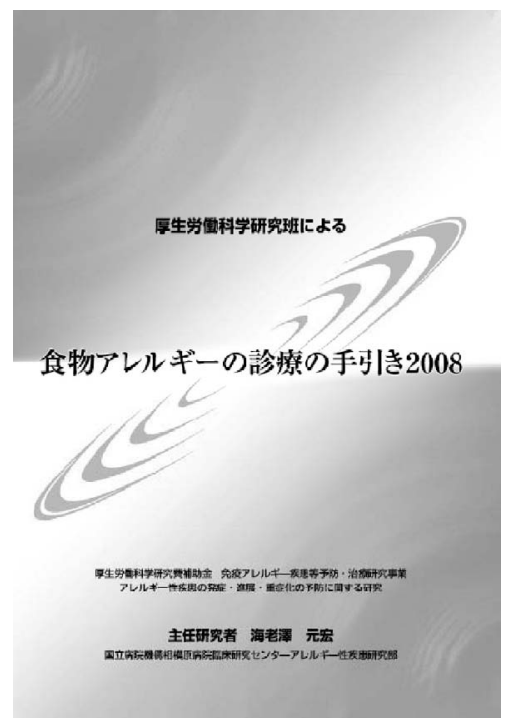

【内 容】

1. 食物アレルギー総論

2. 食物アレルギーの診断

3. 食物アレルギーの治療・予防

4. アナフィラキシー (FEIAn/FDEIA を 含む）への対応

5. 食物アレルギーと栄養

6. 食物アレルギーの社会的対応

7. 参考資料
是生労酯科学研究班による
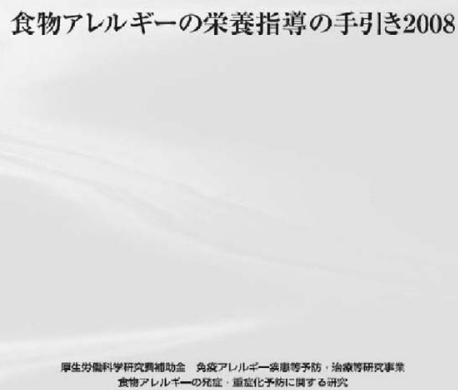

主任研然者今井拳成 min

\section{【内 容】}

1. 栄養指導の目的

2 . 栄養指導の主な実施時期

3. 栄養指導前の確認事項

4. 栄養指導項目と要点

5 . 除去食物別の栄養指導の要点

6. 除去食物別の具体的な解説例

7. 加工食品のアレルギー表示について

8。医師とともに患者や保護者を支援

9. 食物アレルギー患者の現状（背景）

国立病院機構相模原病院臨床研究センター

http://www.hosp.go.jp/\%7Esagami/rinken/crc/index.html

食物アレルギー研究会

http://foodallergy.jp/

財団法人 日本アレルギー協会

http://www.jaanet.org/guideline/05_syoku/index.html

リウマチ・アレルギー情報センター

http://www.allergy.go.jp/allergy/guideline/05/index.html

写真 2 「食物アレルギーの診療の手引き2008」「食物アレルギーの栄養指導の手引き2008」表紙と掲載ホームページ

\section{経過によって保護者の悩みは変化する}

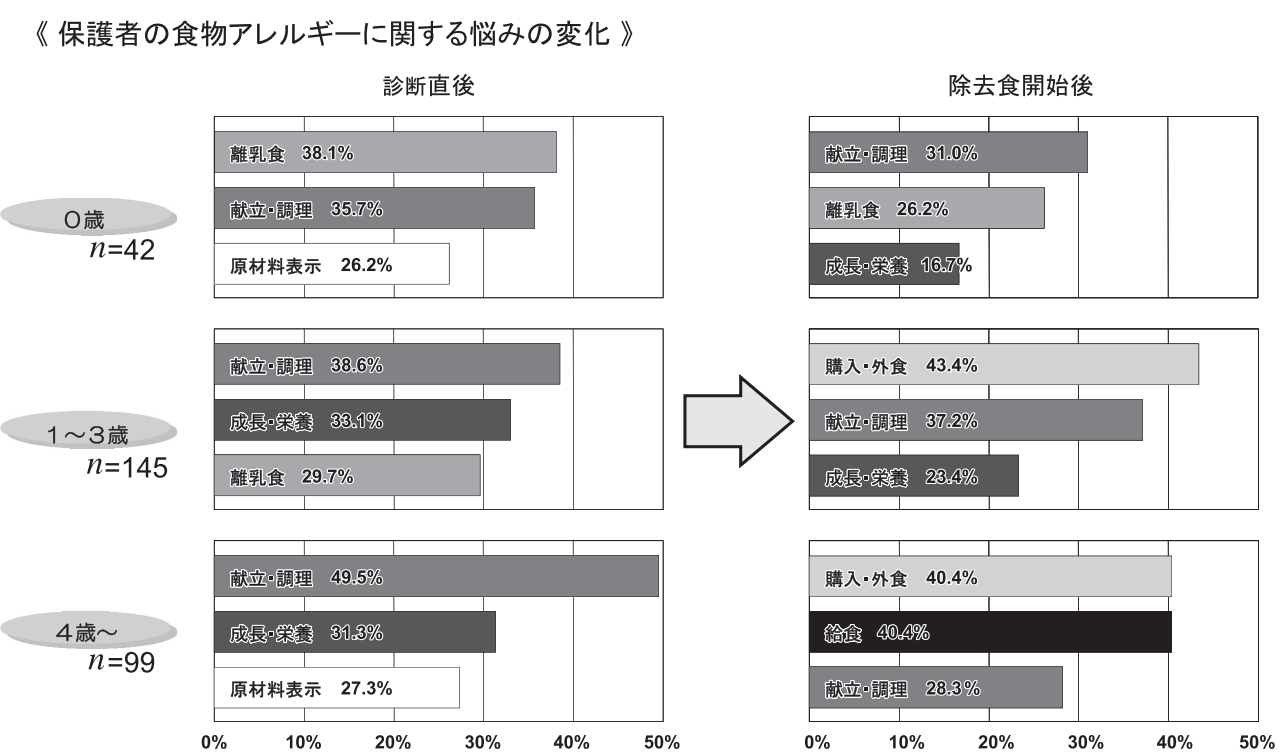

図 1 食物アレルギーの栄養指導の手引き2008 12P 
アレルギーに関する悩みを軽減, 解消しながら豊かな暮 らしを送る「楽しい食生活」への支援を, 医師や管理栄 養士，その他のコメディカルが協力して行う必要がある。

栄養指導では, 医師から除去食物の指示という方向性 を示された患者に対し，“どのようなものを除去すればい いのか”，“食物除去をしながらどうやって生活すればい いのか”という疑問や不安を解消する具体的な方法を伝 え, 食物除去を生活に取り入れる支援をすることが重要 となる。日々の食生活の中から, 指示された食物をただ 単純に取り除くだけでなく, 具体的に栄養面や調理面で その代わりになるものを理解し, 不安なく, 健全な食生 活を送ることができるようにする。

また，食物アレルギー患者の悩みは診断時に限ったこ とではなく, 食物アレルギーに対して理解や対応が未だ 充分であるとはいえない社会生活の中で，除去食を継続 していく上での悩みは子どもの成長とともに多様化する （図 1 ）。食物アレルギー患者の保護者では, 成長期の子 を持つ育児不安と相乗的に悩みや不安が増大する場合も あり, 患者の生活, 年齢に応じた適切な支援を継続的に 行っていくことが求められる。

3. 栄養指導前の確認事項一食物アレルギーについて の正しい理解一

食物アレルギーは，患者によって原因食物や，それを 食べることによって引き起こされる症状がさまざまであ り, 除去の指示や程度も個々に異なる。医師による食物 除去の指示にあわせて，適切な指導ができるよう，その 患者の原因食物はもちろん, 誘発される症状の重篤度な どについても管理栄養士があらかじめ確認しておくこと が重要となる。

また, 栄養指導を行う前に, 栄養士自身が食物アレル ギーについて正しい知識を身につけることが必須である。 例えば，牛乳アレルギー患者ではカルシウムの摂取が不 足しやすいことや, 魚アレルギーで魚種を白身魚, 青身 魚など，色で区別することには根拠がないこと，一般的 な酱油には原材料に小麦と書かれているが製造工程でそ のたんぱく質が分解され残存しないため小麦アレルギー であっても除去する必要が基本的にないことなど, 臨床 における栄養面や診療面での最新の情報を身につける必 要がある。管理栄養士は常に正しい情報を得て, 患者の 除去に伴う負担を最小限にしていくことが求められる。 患者の不安を不必要に㮼ったり, 安易にインターネット や一部の書籍に氾濫する根拠の無い情報を伝えたりする など, 専門的な立場として患者に誤解を与えるような指 導は避けなければならない。

\section{4. 栄養指導の項目と要点}

1 ）食物アレルギーの基本指導

すべての食物アレルギー患者は，まず食物アレルギー
に対する正しい知識を身につけ，適切に除去をしながら 代替食物から必要な栄養素を摂取する方法を理解するこ とが必要である。

a ）現在の食物摂取状況の把握, 評価

栄養指導では，まず医師の指示する患者の除去食物を 確認する。食物アレルギー患者の中には, 症状出現への 不安や誤った情報などから，医師から指示された除去食 物以外にも自己判断で食物を除去している場合もあり， 除去する必要のないものを適切に摂取するよう促すこと も必要である。そのため, 患者が医師の指示する除去食 物を正しく理解しているか，また，現在どのような食物 を摂取していて，どのようなものを避けているかなど， その食生活全般を把握することが重要であり, その上で, 患者の食習慣に合わせた支援を行っていく。

b ）食物除去について／具体的な献立提供

除去食物と, その食物を使った加工食品や料理を含め, “何が食べられないか”，それに対して，栄養面や調理面 で“何が代わりになるか”を具体的に示し，患者が理解 できるようにすることが重要となる。手引きには，実際 の除去食物の解説として, 代表的な鵎卵, 乳, 小麦, 大 豆を除去する際のそれぞれの要点をまとめ，そのまま複 写して患者に配布する資料としても使えるようになって いるので利用していただきたい（図 2 )。そして，患者の 年齢, 性別, 除去食物にあわせた献立例を示し, どのよ うなものを，どれくらい食べればよいかを具体的に想像 できるようにする。

また，その家庭で日常的に使用する調味料や加工食品 などが除去により使用できない場合には, 代替調味料や,

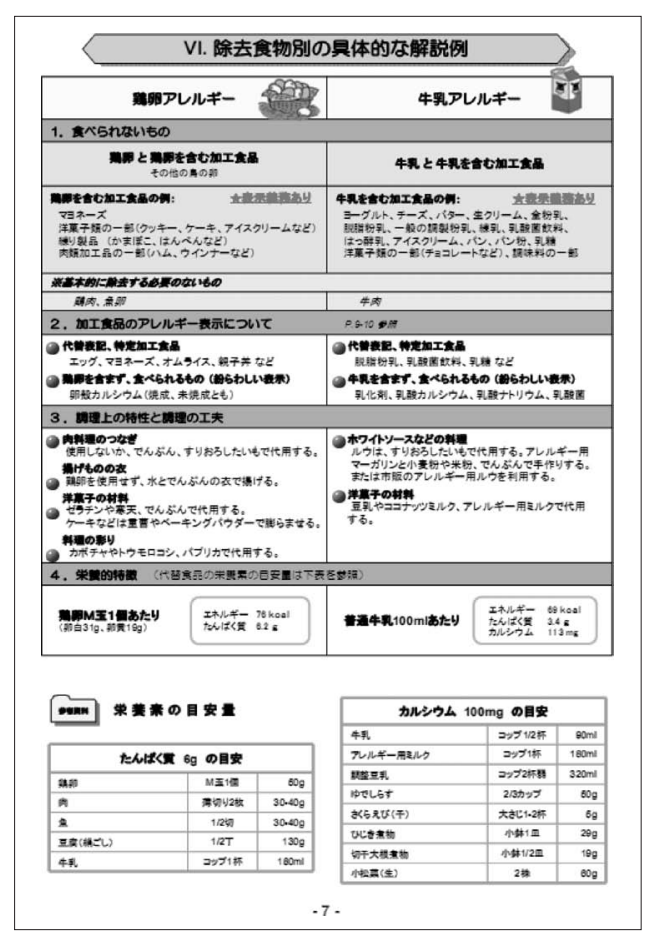

図 2 除去食物別の具体的な解説例 
アレルギー用食品の利用や購入方法などを具体的な例を 挙げて説明する。除去品目が多岐にわたる場合には, 個 別調理やアレルギー用食品の購入などによる調理時間や 経済的な負担も考慮し, 簡便な調理方法や, スーパーな どで手軽に買える食材の中から使用できるものを紹介す ることも重要である。

c）混入や誤食を避ける為の注意点

なるべく患者専用の食器や調理器具を用意することが 望ましいが，家族と共有する場合には充分に洗浄して使 用することや, 患者の食事は家族の食事より先に調理し, 調理後すぐラップやふたをしておくといった，混入防止 のための具体的な注意点を説明する。兄弟がいる場合に は兄弟の食べこぼしなどによる誤食にも注意を促す。

d）加工食品のアレルギー表示について

容器包装された加工食品にはアレルギー表示の義務が あり, 患者や家族はアレルギー表示について正しく理解 することで食品選択の幅が広がり，また誤食の防止にも つながる。しかし，その学習機会は多いとは言えず，患 者の中に誤解があることも少なくない。

正しく表示を理解し，より有効に活用するために，ま ず，患者の除去食物が特定原材料（表示義務がある）か そうでないかを確認することが重要である。表示義務が ある場合には，その代替表記や特定加工食品などの「替 わりの表示」として認められているものや, 患者が混乱 しやすい, 紛らわしい表示 (例: 乳化郕は, 牛乳と直接 関係のあるものではない, など）について説明し，表示 を見て原因食物が加工食品に含まれているかどうかを適 切に判断できるようにする。

また，外食や対面販売の惣菜などは特定原材料であっ てもアレルギー表示の適応にないことを確認し，それら の利用は慎重に検討する必要があることも説明する。一 方で, 特定原材料以外の表示義務がない食品については, 加工食品に使用されていても表示が省略されている可能 性があること, 確実に確認するためにはメーカーに問合 せをする必要があるということを区別しなくてはならな い。厚生労働省から発行されている「加工食品のアレル ギー表示」のパンフレットは，患者自身が表示について 理解するための資料として利用することができ, 有用で ある。

\section{2 ）食物除去の考え方}

食物アレルギー患者の中には，専門の医師以外から 誤った指導を受けていた経験や，書籍やインターネット などに汇濫する情報から得た誤った知識に基づいて, 不 適切な除去をしている場合もある。その場合には医師と 相談しながら, 症状を引き起こさないことを目的とした 必要最小限の除去を指導し, 不要な除去による負担を出 来る限り軽減させることが重要である。

\section{3 ）解除の進め方}

これまで除去していた食物が食物負荷試験などによっ て解除され，食べられるようになった場合には，具体的 に解除された食物の量に見合った調理法や食品の例をあ げ，日常生活に取り入れることが出来るようにする。し かし，中には医師からの解除指示があっても，患者自身 や保護者の不安や恐怖心から食べさせることができず, 解除が進まない場合がある。その場合には，患者や保護 者が安心して食べられる方法を相談し，患者自身の恐怖 心が原因の場合には，たとえば本人にはわからないよう に患者が好む料理に利用し，食べても大丈夫だという自 信をつけていくなどの工夫を助言する。

\section{4 ）栄養評価}

除去品目数が多い場合や，摂取量の不足などにより， 除去を継続する上で栄養上の問題が示唆される場合に は，3 日間の食事記録などから詳細な栄養評価を行う。 不足している栄養素があればそれを明示し，具体的に補 う食品やその料理法を説明し，摂取を促す。

5 ）離乳食

食物アレルギーがあることで，離乳食の進め方に悩む 保護者は多く，中には症状が出現することへの不安から， いつまでも決まった食物しか食べさせられないでいる場 合もある。離乳食は，食物アレルギーであっても特に医 師の指示がなければ基本的に厚生労働省策定の「授乳・ 離乳の支援ガイド」に基づいて進めて問題なく，むしろ 保護者の管理が行き届くこの時期に，その月齢に応じた さまざまな食品を試しておくことが重要とも言える。初 めて食べさせる食物は，“患者の体調のいいとき”に，

“新鮮な食材”を使い，“充分に加熱”をした上で，“少量 ずつ”試し, 症状が出てもすぐに医師の診察を受けるこ とができる“平日の昼間の時間帯”を選ぶなど，より安 心して進められる方法を助言する。

6 ）患者, 保護者の悩み対応

除去食を継続していく中で，家族の協力が得られない 場合や献立作成に行き詰まったとき，園や学校での対応 についてなど，患者の成長に伴って生じる多様な悩みに ついても患者や保護者の支援を行う。管理栄養士の立場 から具体的なアドバイスを行うことや，医師と相談しな がら，患者の負担を軽減できるようにしていく。

\section{5. 医師とともに患者を支援}

食物アレルギー患者は，適切に除去を行うことで症状 を起こすことなく健康に過ごすことができる。しかし逆 に症状がないために，周囲から“本当に食物アレルギー なのか”，“神経質になりすぎているのではないか”など という目で見られ，理解が得られないことも少なくない。 その上相談相手が見つけられず，保護者が悩みや不安を 抱え孤立してしまうこともある。さらに，微量でも重篤 
な症状が出現する場合や，除去品目数が多岐にわたるよ うな場合には, 症状への不安から, 患者や保護者の心理 的な負担はさらに増大する。限られた診療時間内では患 者が医師と充分に話ができないことや，患者や保護者が 悩みを直接医師には相談しづらい場合もあり, 栄養指導 では患者の話に耳を傾け，必ずしも直接的な支援をする だけでなく，管理栄養士が患者との接点となって医師へ 必要な情報をフィードバックするなど， より患者に身近 な立場から，医師とともに患者と保護者の不安を軽減し その食生活を楽しむための支援をしていくことも重要な 役割と言える。

\section{文}

\section{献}

1) Ebisawa, M.: Management of Food Allergy (Food Allergy Management 2005 by National Food Allergy Research Group), Arerugi 2006, 55, 107-114

2）海老澤元宏編：食物アレルギー（小児アレルギーシ リーズ)，株式会社診断と治療社

3）海老澤元宏 : 食物アレルギーへの対応について一厚生 労働科学研究班による「食物アレルギーの診療の手引き 2005」一，アレルギー, 55(2), 107-114（2006）

4）池松か子り, 田知本寛, 杉崎千鶴子, 宿谷明紀, 海老 澤元宏 : 乳児期発症食物アレルギーに関する検討（第 1 報）一乳児アトピー性皮膚炎と食物アレルギーの関係一, アレルギー, 55(2), 140-150（2006）
5）井口正道，宿谷明紀，小俣貴嗣，田知本寛，海老澤元 宏：入院加療した食物アレルギー合併乳児重症アトピー 性皮膚炎患者に関する検討（第 1 報），日本小巟科学会雑 誌，110(11), 1534-1539（2006）

6）池松かおり，田知本寛，杉崎千鶴子，宿谷明紀，海老 澤元宏 : 乳児期発症食物アレルギーに関する検討（第 2 報）一卵・牛乳・小麦・大豆アレルギーの 3 歳までの経 年的変化一，アレルギー，55(5)，533-541（2006）

7）井口正道，宿谷明紀，小俣貴嗣，田知本寛，海老澤元 宏：入院加療した食物アレルギー合併乳児重症アトピー 性皮膚炎患者に関する検討（第 2 報），日本小児科学会雑 誌, 110(11), 1540-1544（2006）

8）厚生労働科学研究費補助金免疫アレルギー疾患予防・ 治療研究事業（主任研究者：海老澤元宏）：食物アレル ギーの診療の手引き 2008

9) Ebisawa, M.: Management of food allergy in Japan "food allergy management guideline 2008 (revision from 2005)" and "guidelines for the treatment of allergic diseases in schools". Allergol Int., 58, 475-83 (2009)

10) Longo, G., Barbi, E., Berti, I., Meneghetti, R., Pittalis, A., Ronfani, L. and Ventura, A.: Specific oral tolerance induction in children with very severe cows milk-induced reactions. J Allergy Clin Immunol., 121, 343-7 (2008)

11）厚生労働科学研究費補助金免疫アレルギー疾患予防・ 治療研究事業（主任研究者：今井孝成）：食物アレルギー の栄養指導の手引き 2008

（受付：平成21年12月 30 日，受理：平成22年 3 月 31 日） 